\title{
Effect of a Unani Formulation in Unexplained Primary Infertility - A Case Report
}

\author{
Ismath Shameem* and Ghazala Ahmad \\ Department of Ilmul Qabalat wa Amraze Niswan, National Institute of Unani Medicine, India
}

Submission: August 08, 2019 , Published: August 13, 2019

*Corresponding author: Ismath Shameem, Department of Ilmul Qabalat wa Amraze Niswan, National Institute of Unani Medicine, India

\section{Abstract}

Background: Unexplained infertility is a frustrating diagnosis both for the patient and the clinician, with a prevalence of $16 \%$ - $37 \%$. It commonly refers to a 'diagnosis' made when tubal, ovulatory and husband factors are ruled out. A couple is usually referred for evaluation after 1 year of unsuccessful trials of conception with unprotected intercourse in the fertile phase of the menstrual cycle. Unani formulation comprises of baikh asgand (Withania somnifera Dunal), baikh piyabansa (Barleria prionitis Linn), gule dhawa (Anogeissus latifolia) and gule nilofar (Nymphaea alba Linn) were used for the treatment of uqr, possessing the properties of muqawwi rahim, moaene hamal, moallide mani, etc.

Case presentation: A married couple (22 years female partner \& 26 years male partner) presented to NIUM Hospital OPD, with chief complaint of failure to conceive since 5 years. The couple report a high degree of stress related to their lack of success. Investigations were carried to check for tubal patency, ovulatory function and semen analysis. Diagnosis of unexplained infertility was made after thorough evaluation of the case. The powder of above mentioned formulation was given $6 \mathrm{~g}$ twice a day orally with milk from 5 th day of cycle for 5 days. Patient got conceived after taking treatment for two consecutive cycles.

Discussion: Here we report evidence based management with Unani medicine to help combat the significant physical, psychosocial and economic toll on couples.

Keywords: Unexplained infertility; Primary infertility; Uqr; Muqawwi rahim; Moaene hamal; Moallide mani; Unani medicine

\section{Introduction}

Infertility is usually described as 1 year of unwanted non-conception with unprotected intercourse in the fertile phase of the menstrual cycle [1]. Upto $30 \%$ of couple who are unable to conceive are determined to have unexplained infertility \& this diagnosis is made only after the basic infertility evaluation fails to reveal an obvious abnormality [2]. A couple is usually referred for evaluation after unsuccessful trials of conception for a period of 1 year [1,3]. The basic evaluation should provide evidence of ovulation, patency of fallopian tubes \& adequate sperm production. Couples with unexplained infertility suffered from both diminished \& delayed fecundity [1,2]. Some couples suffer from unexplained infertility either due to undetected, subtle defects of reproductive process or by chance alone, couples have low fecundity. Question of low fecundity must be raised after six cycles of unprotected intercourse without conception regardless of age. Decision of treatment depends on prognostic factors such as duration of infertility and age of female partner; shorter duration of infertility ( $<2$ years) and female age $<30$ years are related to higher cumulative pregnancy rates. Each additional month of infertility beyond the average reduces the chance of pregnancy by $2 \%$ or about $25 \%$ per year [1].

In classical Unani text, uqr (infertility) is defined as when conception fails to occur or when there is a difficulty in conception either due to the defect in male or female partner. Concept of idiopathic infertility [4] is also mentioned in classical literature. Various formulations have been mentioned for the treatment of uqr, possessing the properties of muqawwi rahim, moaene hamal and moallide mani which are to be used from the 5th day of menstrual cycle [5,6] (corresponds to ovulation inducing drugs), as conception is most likely to take place after menstruation. Such types of drugs are known to contain phytoestrogens and may induce ovulation by maintaining hormonal balance. We report a case of unexplained primary infertility in which the effect of Unani formulation was explored. The study is aimed to exhib- 
it the implication and usefulness of Unani medicine synergistic effect to obtain optimal patient outcome in case of unexplained primary infertility.

\section{Case Presentation}

A married couple (22 years female partner \& 26 years male partner) presented to OPD of NIUM Hospital with the complaint of a possible fertility issue. The couple has been married for 5 years and since then has been trying to conceive and report a high degree of stress related to their lack of success. Patient had regular menstrual cycle of 28-30 days with 4-5 days' duration of flow of moderate amount. The couple had never sought any treatment for the same. She had moderate built with no significant medical or surgical history. There was no history of consanguineous marriage and family infertility on either side of partners. The patient was a housewife, belongs to low socio economic group and had no history of STDs, smoking, alcohol or other drug. The patient's partner also reported good health and no problems with erection, ejaculation or pain during intercourse. He had no prior urogenital infections or exposure to STDs \& no significant medical or surgical history. He works as a garment factory worker and had no habits of smoking, alcoholism, drug abuse or self-medications. The couple had vaginal intercourse 3-4 times per week.

On examination, her vitals were stable, breast revealed no tenderness or palpable lump, bilateral chest was clear, normal vesicular breathing sound \& S1 \& S2 were audible with no murmur and per abdomen was soft and nontender. Per vaginal examination revealed anteverted, normal sized, mobile and firm uterus with no fornicial tenderness. Investigation recommended were semen analysis for male partner and $\mathrm{CBC}$, ABO Rh typing, CUE, FBS, AMH, D2 S. FSH, S. LH, PRL, TSH levels \& TVS for antral follicle count and HSG on D9 of cycle for female partner. Husband semen analysis was normal with 104 million sperm count, normal morphology and good motility, while female partner had B positive blood group, Hb\% 12.5gm/dl, FBS 88mg/dl, AMH 2ng/ $\mathrm{ml} \&$ her hormonal profile was FSH 7.8IU/L, LH 2.45IU/L, PRL $15 \mathrm{ng} / \mathrm{ml}$, TSH $2.3 \mathrm{mU} / \mathrm{L}$ on D2 of cycle. HSG showed normal uter- ine cavity and fallopian tube with bilateral spillage in peritoneal cavity. TVS on D2 of cycle showed good antral follicle count without any pelvic pathology.

\section{Intervention}

Unani formulation comprises of baikh asgand (Withania somnifera Dunal), baikh piyabansa (Barleria prionitis Linn), gule dhawa (Anogeissus latifolia) and gule nilofar (Nymphaea alba Linn) 4 were taken in a dose of $50 \mathrm{~g}$ each and grinded to make fine powder. Patient was advised to take $6 \mathrm{~g}$ powder twice daily orally with milk for 5 days started from 5 th day of menstrual cycle for 2 consecutive cycles. Patient was instructed to have timed intercourse.

\section{Follow Up \& End Result}

Patient took the Unani medicine for two consecutive cycles. No response was observed in first cycle, and then she was counselled and advised to continue the same in the next cycle. After receiving Unani medicine in second cycle, she had missed her period \& urine for pregnancy test was positive. This pregnant woman had regular ANC till 9 months at NIUM Hospital \& successfully delivered a male baby of $3 \mathrm{~kg}$ weight at Govt. Hospital and her pregnancy \& puerperal period was uneventful.

\section{Discussion}

A couple is usually referred for evaluation after unsuccessful trials of conception for a period of 1 year.2,3 The Practice Committee bulletin on unexplained infertility mentioned that the basic evaluation should provide evidence of ovulation, adequate sperm production and fallopian tube patency, all of these were evaluated in this case [2]. Decision of treatment depends on prognostic factors such as duration of infertility and age of female partner, shorter duration of infertility ( $<2$ years) and female age $<30$ years are related to higher cumulative pregnancy rates. Each additional month of infertility beyond the average reduces the chance of pregnancy by $2 \%$ or about $25 \%$ per year [1]. In this case, though the patient's age was 22 years but she fails to conceive even after 5 years of unprotected intercourse, which indicates the need for the treatment.

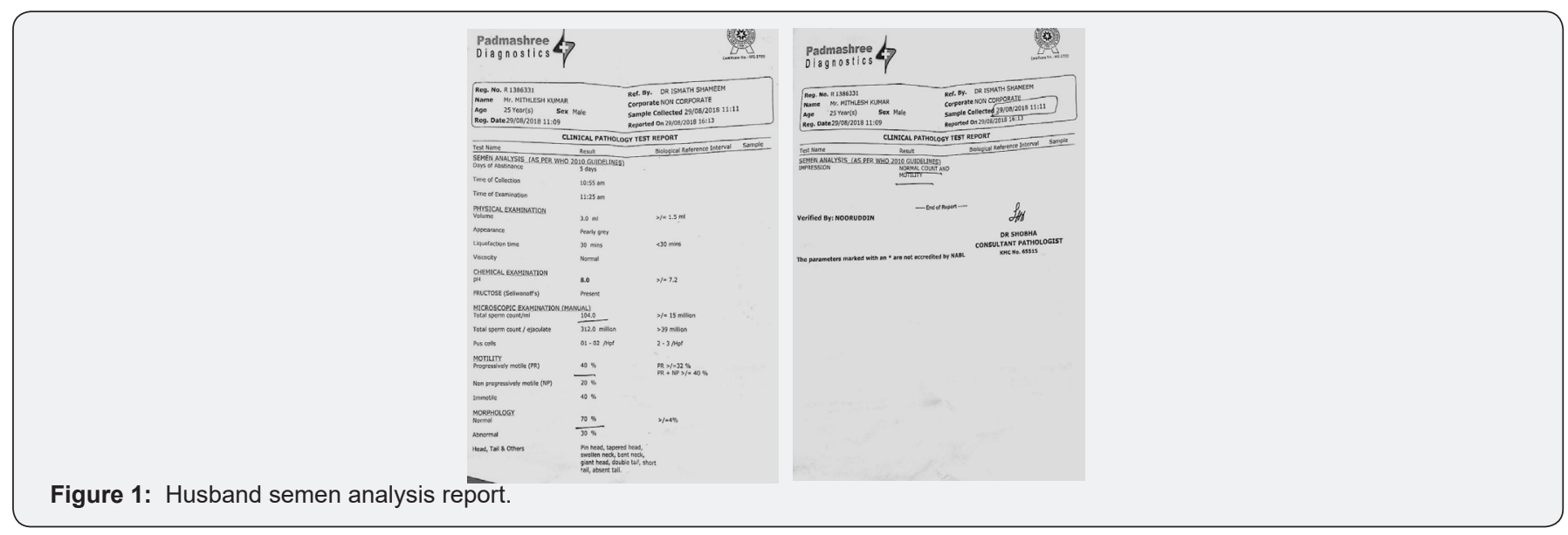



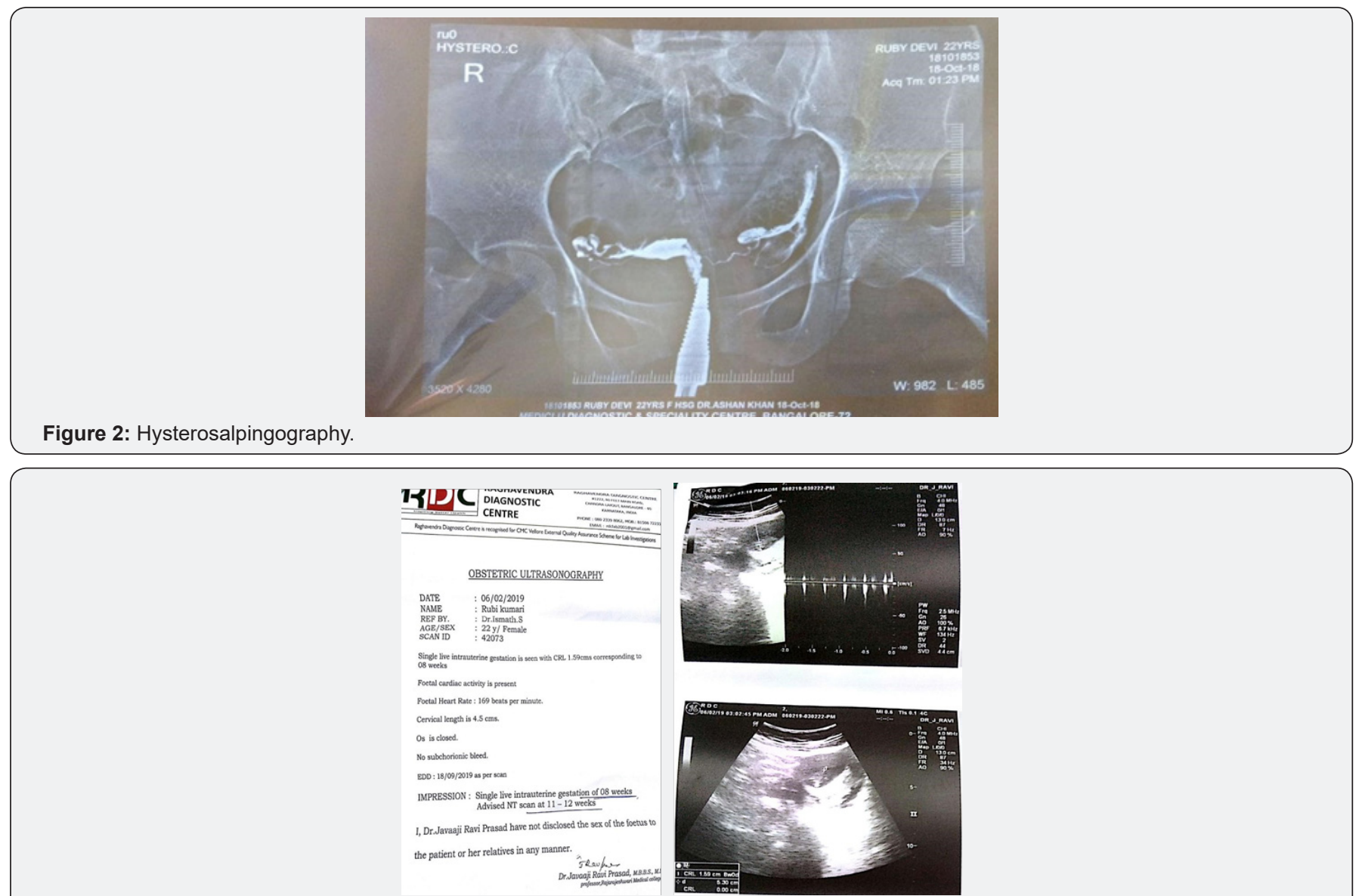

Figure 3: Dating ultrasonography.

Baikh asgand (Withania somnifera Dunal), baikh piyabansa (Barleria prionitis Linn), gule dhawa (Anogeissus latifolia) and gule nilofar (Nymphaea alba Linn) are muqawwi rahim, moaene hamal and increases the madda manwia; hence useful in uqr as it induces the ovulation [4,7]. Asgand contains alkaloids and steroidal lactones are the main constituents, gul dhawa consist of (saponins, tannin quercetin, phenolic compounds), gule nilofar is rich in alkaloids, whereas piyabansa contain anthraquinone pigmented, barleriaquinone, all are responsible for phytoandrogen-oogenic, antistress and insulin sensitising activities [8-10]. For detection of ovulation, serial follicular monitoring is the gold standard method which was not done in this case as she was not affordable, but the confirmatory test is pregnancy which was positive in this case. Unani medicine helped the patient to conceive within two cycles of treatment, without any observable side effects. Further comparative studies, with serial follicular monitoring \& mid luteal serum progesterone may be helpful to establish the effectiveness of Unani medicines in such cases (Figure 1-3).

\section{References}

1. Ray A, Shah A, Gudi A, Homburg R (2012) Unexplained infertility: an update and review of practice. Reprod Biomedicine Online 24(6): 591602.
2. Birmingham A (2006) Effectiveness and treatment for unexplained infertility. The practice committee of the ARSM 86(4): 111-114.

3. National Institute of Clinical Excellence (2004) Clinical guidelines 11 fertility: assessment and treatment for people with fertility problems.

4. Khan HA, Al Akseer (2011) In: Kabeeruddin M(Eds), In: (1 ${ }^{\text {st }}$ edn), Idara Kitab-us-Shifa. New Delhi, India, pp. 819-21.

5. Majoosi ABA, Kamilus Sana (2010) In: Kantoori GH (.Ed), Vol I \& II, Idara Kitab-us- Shifa, New Delhi, India, 538(40): 498-499.

6. Ibn Sina, Al Qanoon Fil Tib (2010) In: Kantoori GH (.Ed), Idara Kitabus-Shifa, New Delhi, India 1065(70): 1445-1447.

7. Ghani N, Khazainul A (2011) Idara Kitab-us- Shifa, New Delhi, India 887(1156): 1271-1272.

8. Anonymous (2003) The Wealth of India, Raw materials. CSIR, New Delhi, India 46(48): 581-585.

9. Gupta AK, Tandon N (2004) Review of Indian medicinal plants. ICMR, New Delhi, India pp. 373-376.

10. Satyavati GV, Gupta AK (1987) Medicinal plants of India Vol II. ICMR, New Delhi, India pp. 347-351. 
(C) Commons Attribution 4.0 License Commol: 10.19080/JGWH.2019.16.555931
DO

\section{Your next submission with Juniper Publishers} will reach you the below assets

- Quality Editorial service

- Swift Peer Review

- Reprints availability

- E-prints Service

- Manuscript Podcast for convenient understanding

- Global attainment for your research

- Manuscript accessibility in different formats

( Pdf, E-pub, Full Tsext, Audio)

- Unceasing customer service

Track the below URL for one-step submission https://juniperpublishers.com/online-submission.php 